Andrea Vuković ${ }^{1}$ Dragana Ubiparip ${ }^{2}$ Maja Radovanović ${ }^{3}$ Sonja Jaćimović ${ }^{4}$
JEL: Q1, 013, P32

DOI: 10.5937/industrija43-9166

UDC: $338.439 .5: 339.564(497.11)$ 338.439.4:635.64

Original Scientific Paper

\title{
Fresh tomato: promising export product for Serbia? ${ }^{5}$
}

Article history:

Received: 4 May 2015

Sent for revision: 2 June 2015

Received in revised form: 19 August 2015

Accepted: 1 September 2015

Available online: 15 October 2015

\begin{abstract}
Production of fresh vegetable is in Serbia often emphasized as a sector with promising export potential. However, available analysis and recommendations are mainly of general character without comprehensive data enabling applicable recommendations for improved utilization of existing potentials. In order to enable thorough insight into the sector of production of fresh tomato and its export potentials, analysis of production and international trade trends in Serbia and potential target markets was conducted based on statistical data. Additionally, tomato supply chain structure in Serbia was reviewed based on a series of interviews. Obtained results pointed out at the markets of Central and Eastern Europe as potential target markets for fresh tomato from Serbia, but indicated a number of improvements that are prerequisite for competitive utilization of fresh tomato production potentials in Serbia. Improvements are needed in production practices leading to improvement of quantity, quality, safety and uniformity of produced tomato, but above all in organization of supply chain.
\end{abstract}

Keywords: tomato, international trade, export, competitiveness, supply chain

\section{Svež paradajz: obećavajući izvozni proizvod za Srbiju?}

Apstrakt: Proizvodnja svežeg povrća se u Srbiji često ističe kao sektor sa značajnim izvoznim potencijalom. Međutim, postojeće analize i preporuke su

\footnotetext{
${ }^{1}$ Economics institute, Belgrade, Kralja Milana 16, Serbia, andrea.vukovic@ecinst.org.rs

2 University of Novi Sad, Faculty of Agriculture, PhD, student

${ }^{3}$ University of Novi Sad, Faculty of Agriculture, PhD, student

${ }^{4}$ Economics institute, Belgrade

${ }^{5}$ Presented research is the result of the project III 46001 funded by the Ministry of education, science and technological development of Republic of Serbia
} 
uglavnom opšteg karaktera bez sveobuhvatnih podataka koji bi omogućili davanje preporuka za unapređenje iskorišćenja postojećih potencijala. Sa ciljem dobijanja temeljnog uvida u sektor proizvodnje svežeg paradajza $i$ njegov izvozni potencijal na osovu raspoloživih statističkih podataka izvršena je analiza trendova proizvodnje $i$ spoljnotrgovinske razmene u Srbiji $i$ na potencijalnim ciljnim tržištima, a na bazi niza intervjua izvršen je uvid u lanac snabdevanja paradajzom u Srbiji. Dobijeni rezultati ukazali su na tržište centralne $i$ istočne Evrope kao potencijlno ciljno tržište za svež paradajz iz Srbije, ali ukazali su i na brojna poboljšanja koja su preduslov za konkurentno iskorišćenje potencijala za proizvodnju paradjza u Srbiji. Poboljšanja su potrebna kako u proizvodnoj praksi u pracu povećanja količina, unapređenja kvaliteta, bezbednosti i ujednačenosti proizvedenog paradajza, ali pre svega $u$ organizaciji lanca snabdevanja.

Ključne reči: paradajz, spoljnotrgovinska razmena, izvoz, konkurentnost, lanac snabdevanja

\section{Introduction}

Recently published results (Ignjatijević et al., 2014) directed at analysis of comparative advantages of agri-food products from Serbia regarding their potential to contribute to the increase of exports from Serbia indicated that, among other products, vegetables are characterized with increase of comparative advantage for exports as measured by the Balassa index. The position of Serbia at international fresh vegetable market was analyzed by Đorović et al. (2008) in respect to general trends of international trade and in comparison to the leading countries in fresh produce exports and pointed out at the fact that trends, requirements and development possibilities differ significantly among vegetable production sectors. However, based on analysis of harvested areas and yields of vegetables in Serbia, Puškarić et al. (2009) pointed out at a list of problems influencing insufficient volumes and inacceptable quality of vegetables as the main obstacles for realization of potential of vegetable sector for export.

Mentioned results point out at undoubtedly existing, but in reality unutilized potential of fresh vegetable sector to be one of the key contributors to total exports from Serbia. Nevertheless, general considerations regarding the problems and obstacles preventing positioning of fresh vegetable production sector as one of the meaningful export sectors, available in scarce research published in this field, are not sufficient for comprehensive understanding of current situation and development of viable plans for its overcoming.

However, the sources of existing problems and consequently viable solutions differ significantly among the vegetable production sectors. In order to 
conduct in depth analysis of potentials and problems for increasing of exports from Serbia, tomato production sector was chosen as a model for conduction of production, supply chain, export markets and competition analysis based on which recommendations for measures directed at optimal utilization of existing resources could be defined.

\section{Literature review}

During the past decades, from the commodity with strictly seasonal consumption, tomato became a part of consumers' daily menus all year around (Rodríguez and Hernández, 2005). Development of production technology and supply chains enabled continuous supply of fresh tomato to the markets of developed economies, as well as its availability year around at the markets of developing countries. This was the main factor enabling the shift of consumers' habits related to seasonal consumption of fresh tomato and creation of a constant demand for fresh tomato year around (Anastasiadis and van Dam, 2014).

On the other hand, from production standpoint tomato represents agricultural product requiring relatively high temperature $\left(20-25^{\circ} \mathrm{C}\right)$ and sufficient quantity of light (at least 10 hours of light per day) in order to generate acceptable quantity of desired quality fruits. Stated requirements of tomato plant for viable tomato fruit production conditioned the generation of permanent supply with high quality tomato fruits from two principal sources:

- From countries with favorable climate conditions for tomato production in open field or plastic tunnels like Mediterranean countries (Valenciano et al., 2008) or

- From countries that developed and applied technical possibilities supporting tomato production requirements in high-tech conditioned greenhouses like Netherlands (Aramyana et al., 2009)

Successful, year around production is only the first factor supporting positioning of the country as a tomato exporting country. However, in academic literature a diversity of other issues was identified as relevant factors for competitive entrance into global tomato market. Organized supply chain towards markets of developed countries with high tomato consumption, resolved safety issues (Codron a et al., 2014), ability to fulfill demand requirements ((Rodríguez and Hernández, 2005) and ability to be competitive in respect to other exporters (Serin and Civan, 2008 Valenciano et al., 2008) are only some of the major issues studied in relation to tomato export.

Recent developments related to sustainability of supply chains emphasized also the research related to tomato production and distribution life cycle 
analysis (Andrews et al., 2009) and carbon footprint of intensive production and long transport routes of tomato from producer to the consumer (Theurl et al., 2014; Roggeveen, 2014). For tomato, as highly perishable commodity research of losses in the supply chain with discussion of activities directed to losses diminution is also in the focus of researchers' interest (Sharmaa and Singhb, 2011; Venus et al., 2013).

Analysis and modeling of tomato supply chain is unavoidable part of the research activities in countries present or intending to enter the global fresh tomato market. Research regarding the supply chain is conducted intensively in both, countries dominating at the tomato market like Netherlands (Aramyana et al., 2009), Spain (Valenciano et al., 2008; Rodrıguez and Hernandez, 2005), Turkey (Serin and Civan, 2008) and Morocco (Codron a et al., 2014), but also the countries striving to improve their position at the tomato market like Pakistan (Tahir et al., 2012), Ghana (Clottey et al., 2009), Moldova (Stratan, 2014), or the countries of West Africa (Venus et al., 2013).

Significant contribution to and establishment of effective supply chain is provided also by the research activities related to tomato quality determination (Belović et al., 2012; Zdravković et al., 2009), development of postharvest treatments (Belović et al., 2015; Mojević and Tešanović, 2011), storing and manipulation processes (Ponjičin et al., 2012)) and packaging solutions (Radusin et al., 2013) enabling preservation of produced quantities and qualities of fresh tomato.

\section{Research methodology}

In order to obtain and analyze data relevant for understanding of the situation and potentials for tomato production of Serbia and its export potential, various research tools were utilized. On one hand, data about tomato production and international trade in Serbia in past 10 years (2005-2014) were collected and systematized regarding quantities, values and prices. Data bases of Statistical office of Republic of Serbia were used as a source of data (http://webrzs.stat.gov.rs/WebSite/public/ReportView.aspx ). The data related to the analysis of international trade balances at potential target markets for tomato produced in Serbia and existing competition and international trade balances were collected from the database provided by statistical division of FAO - Food and agriculture organization of United Nations (http://faostat3.fao.org/home/E ). On the other hand, a series of semistructured interviews with the most relevant stakeholders was used in order to get the insight into the tomato sector and existing supply chain in Serbia. Interviews were conducted with experts, tomato producers, production advisors, tomato production and storage supplies and equipment producers 
and importers and scientists involved in tomato production and preservation research with the issues of production practices, distribution channels, participants of the supply chains and share of diverse supply chains in total tomato supply in Serbia.

\section{Results and discussion}

In the past decade (2005-2014) the production of tomato in Serbia is characterized with stable growing areas of up to 10.000 hectares (Figure 1), point out of equilibrium in tomato production and distribution existing in Serbia with no significant changes imposed during the past period.

Average yields of tomato in Serbia fluctuate from under $15 \mathrm{t} / \mathrm{ha}$ up to $20 \mathrm{t} / \mathrm{ha}$ (Figure 1) with drops in yield in the years with inconvenient conditions for open field tomato production as a dominant production technology represented in Serbia. The level of achieved tomato yields is far below the potential of existing and in production present tomato varieties for open field production (Takač et al., 2007) and unacceptably low in respect to yield of tomato achieved in semicontroled (up to $100 \mathrm{t} / \mathrm{ha}$ ) or controlled (over $400 \mathrm{t} / \mathrm{ha}$ ) greenhouse production (Asci et al., 2014).

Figure 1. Trends of production areas and average yields for tomato in Serbia (2005-2014)

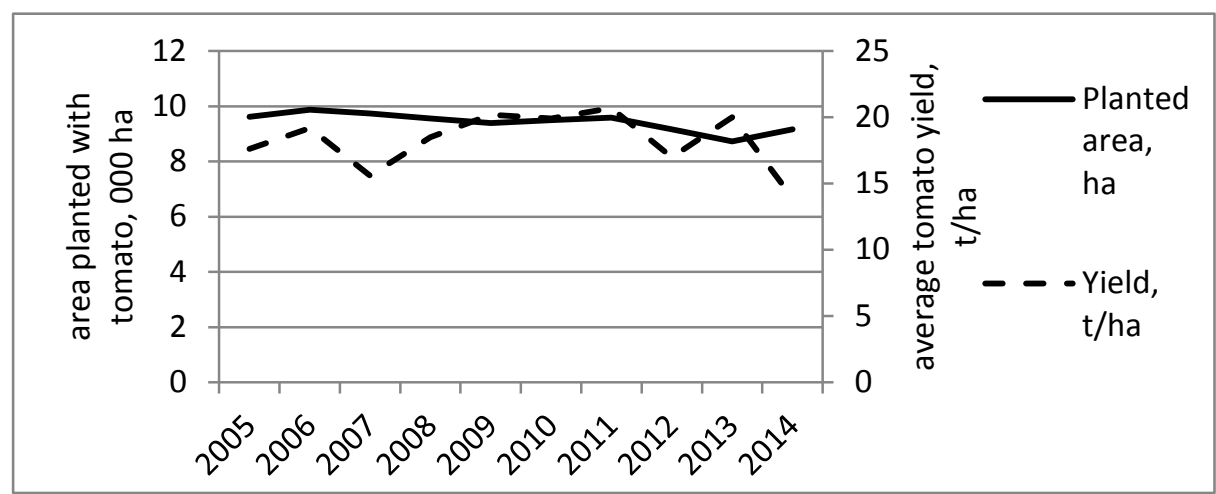

In comparison to total tomato production of Serbia, international trade does not represent significant portion (Figure 2). The main stream in international trade is the import of fresh tomato realized constantly with the quantities of 20.000-25.000 t/year in comparison to annual domestic production at the level 
of $180.000 \mathrm{t}$. The export of fresh tomato is characterized with fluctuating, but yet increasing trend reaching the level ofaround $5.000 \mathrm{t} / \mathrm{year}$. Increasing export trends point out at existing, but slowly implemented activities needed for inclusion of Serbia in the international tomato market.

Tomato supply in Serbia is also characterized with permanent import of tomato semi-products like tomato paste and peeled tomato with annual quantities varying slightly around 5.000 t/year. This observation indicates that quite large portion of tomato semi-products demand is satisfied from Import, in spite of existing domestic production of open field tomato.

The export of tomato products is low in comparison to fresh produce and especially in comparison to production, but it is characterized with constant increase in the past decade.

Figure 2. Trends in tomato production and international trade in Serbia (2005-2014)

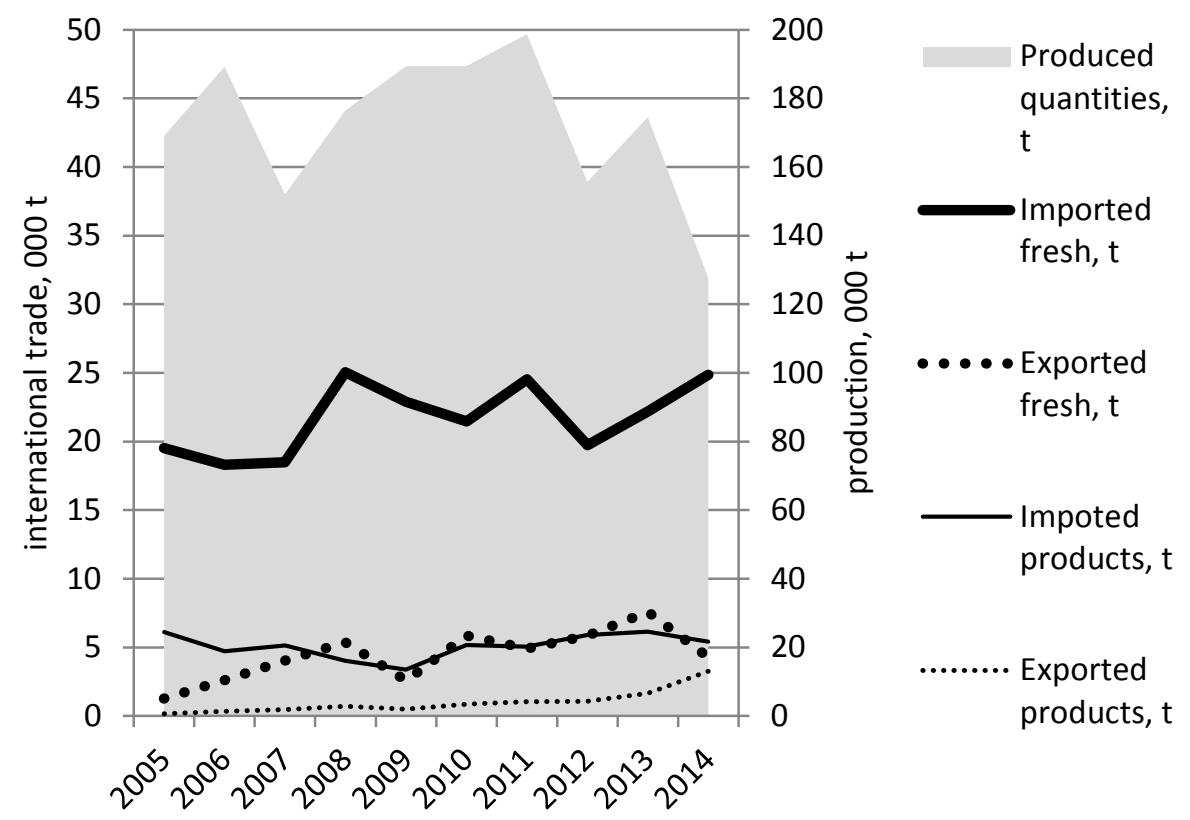

Deeper analysis of international trade balances by countries from which and to which tomato is imported and exported (Table 1) provides better insight into current situation regarding position and practice of Serbian tomato sector in international trade. 
Vuković A. et al.: Fresh tomato: promising export product for Serbia?

Table 1. International trade balances of fresh tomato in Serbia

\begin{tabular}{|c|c|c|c|c|}
\hline \multirow[b]{2}{*}{ Country } & & \multicolumn{2}{|c|}{ Interval of variation } & \multirow{2}{*}{$\begin{array}{l}\text { Variation } \\
\text { coefficient } \\
(\%)\end{array}$} \\
\hline & $\begin{array}{l}\text { Average } \\
(\mathrm{t})\end{array}$ & $\begin{array}{l}\text { Minimum } \\
(\mathrm{t})\end{array}$ & $\begin{array}{c}\text { Maximum } \\
(\mathrm{t})\end{array}$ & \\
\hline \multicolumn{5}{|c|}{ FRESH TOMATO IMPORTS } \\
\hline FYROM & $16.341,4$ & $12.655,5$ & $21.434,9$ & 16 \\
\hline Turkey & $2.461,7$ & $1.068,8$ & $6.544,1$ & 62 \\
\hline Albania & $1.118,4$ & 0,0 & $4.891,1$ & 176 \\
\hline Italy & 556,5 & 54,1 & $1.498,7$ & 81 \\
\hline Spain & 431,9 & 76,6 & 922,3 & 153 \\
\hline Greece & 329,2 & 3,0 & $2.152,7$ & 195 \\
\hline Montenegro & 168,50 & 0,00 & 733,90 & 157 \\
\hline Netherlands & 156,9 & 0,0 & 797,6 & 162 \\
\hline Bosnia \& Herzegovina & 114,3 & 0,0 & 630,0 & 156 \\
\hline Morocco & 68,8 & 11,1 & 267,8 & 111 \\
\hline $\begin{array}{l}\text { Jordan, Syria, Germany, } \\
\text { Poland, Croatia, } \\
\text { Slovenia, Romania, } \\
\text { Belarus, Bulgaria, } \\
\text { Belgium, Russia, Egypt } \\
\text { Tanzania, Israel Trinidad } \\
\text { and Tobago, Senegal, } \\
\text { Honduras }\end{array}$ & Up to 20 & 0,0 & 40,0 & Up to 600 \\
\hline \multicolumn{5}{|c|}{ FRESH TOMATO EXPORTS } \\
\hline Russia & $1.238,6$ & 112,4 & $3.437,9$ & 86,3 \\
\hline Montenegro & $1.162,6$ & 1,10 & $2.181,40$ & 80,9 \\
\hline Bosnia and Herzegovina & 886,9 & 288,20 & $1.886,40$ & 54,7 \\
\hline Bulgaria & 630,6 & 38,90 & $2.087,80$ & 110,7 \\
\hline Belarus & 525,6 & 19,10 & $1.854,80$ & 145,7 \\
\hline Romania & 215,3 & 1,80 & 864,50 & 126,5 \\
\hline Slovenia & 156,6 & 3,60 & 415,10 & 88,4 \\
\hline Greece & 98,9 & 0,00 & 693,10 & 213,4 \\
\hline Croatia & 71,5 & 0,00 & 288,40 & 147,7 \\
\hline Slovakia & 26,5 & 2,10 & 50,00 & 90,3 \\
\hline $\begin{array}{l}\text { Poland, Germany, Italy, } \\
\text { Sweden, Moldova, Czech } \\
\text { Republic, Austria, } \\
\text { Switzerland }\end{array}$ & Up to 20 & 0,0 & 40,0 & Up to 250 \\
\hline
\end{tabular}

Source: Statistical office of Republic of Serbia

Regarding the import, the dominant and the only constant flow is the import of fresh tomato from FYROM. Additional, multiply lower quantities of fresh 
tomato are imported every year to Serbia also from the leading tomato exporters in Europe: Turkey, Italy and Spain, but imported quantities are much lower in comparison to quantities imported from FYROM. Having in mind efforts of FYROM in vegetable export sector (Peševski, 2006) such situation is not surprising. In recent years the import of fresh tomato to Serbia was also initiated. Other sources of fresh tomato are represented in import streams to Serbia occasionally with large number of countries involved (Greece, Montenegro, Netherlands, Bosnia and Herzegovina, Morocco, Jordan, Syria, Germany, Poland, Croatia, Slovenia, Romania, Belarus, Bulgaria, Belgium, Russia, Egypt, Tanzania, Israel Trinidad and Tobago, Senegal, Honduras). This observation points out at inexistence of permanent partner or source for winter supply of tomato that is imported according to actual circumstances with relatively low quantities.

The main export markets for fresh tomato from Serbia are currently Russia (and Belarus), the neighboring countries (Montenegro, Bosnia and Herzegovina, Bulgaria, Romania, Croatia), and the countries from the region (Slovenia and Greece). The export to EU countries (Slovakia, Poland, Moldova, Czech Republic) and especially the ones with developed economies (Germany, Italy, Sweden, Austria, Switzerland) is realized sporadically with negligible quantities.

Presented considerations supplemented with analysis of average import and export prices in Serbian international trade of fresh tomato (Figure 3) point out at the main features characterizing the position of Serbia in international market of fresh tomato.

Imported tomato is represented with two different streams. The first stream is relatively cheap tomato $(0,5-0,7 \mathrm{USD} / \mathrm{kg})$ imported from the countries with convenient climate for tomato production but without high-tech greenhouses for production under controlled conditions. This tomato is usually imported prior to beginning of production season in Serbia from the countries having conditions for earlier start of production season, as well as after the end of production season in Serbia. During the season tomato I partly imported due to the offer at prices lower than the offer from domestic production, and partly due to the deficit of high quality tomato from contemporary greenhouses even in the full production season. The other stream is the high price tomato (0.8$1.1 \mathrm{USD} / \mathrm{kg}$ ) imported from the leading tomato production countries. This import stream satisfies relatively low demand for tomato during the winter period for the market niche willing and able to afford high price tomato and represents less than $10 \%$ of total tomato imports.

Two different streams are present also in the export balance of fresh tomato from Serbia. The first stream includes tomato exported to the regional market at low and sometimes extremely low prices $(0.2-0.5 \mathrm{USD} / \mathrm{kg}$ ) represented in total exports with over $70 \%$. The second stream is exported to markets of 
Russia and Slovenia at acceptable prices (0.6-0.8 USD $/ \mathrm{kg}$ ), but it represents less than $30 \%$ of total exports.

Another observation regarding the prices of tomato in international trade of Serbia is that the import prices are higher than the export ones pointing at even more unfavorable international trade balance regarding the values than the ones emphasized for quantities.

Figure 3. Average prices for fresh tomato in international trade of Serbia (2005-2014)

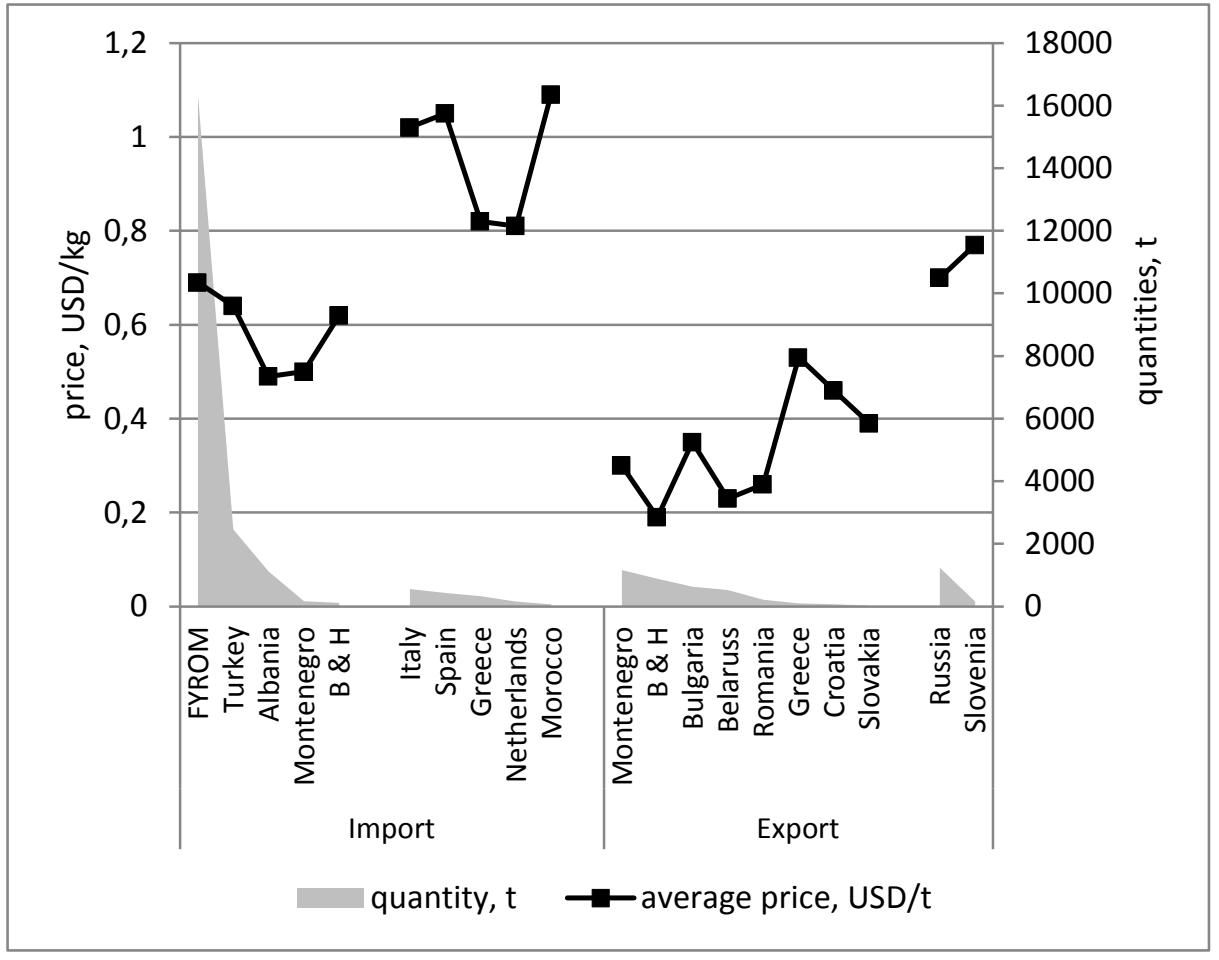

However, increasing trends of tomato export, as well as the existence of small but viable export at relatively high prices point out the potential of Serbian tomato sector for becoming the exporting sector contributing to national economy through sustainable export.

In order to locate potential target markets for fresh tomato from Serbia the analysis of international trade balances for fresh tomato for potential target markets for fresh tomato was conducted, including the markets located at the distances providing beforehand competitive advantage to Serbia in 
Vuković A. et al.: Fresh tomato: promising export product for Serbia?

comparison to distant (oversea) countries based on significantly lower transport costs.

Table 2. Review of international trade balances for fresh tomato for potential target markets for fresh tomato

\begin{tabular}{|c|c|c|}
\hline Market & Countries & $\begin{array}{l}\text { Average } \\
\text { international trade } \\
\text { balance }(\mathrm{t})\end{array}$ \\
\hline \multicolumn{3}{|c|}{ Central European Free Trade - CEFTA 2006} \\
\hline Exporters & FYROM & 42.590 \\
\hline Importers & $\begin{array}{l}\text { Serbia, Croatia, Albania, Moldova, } \\
\text { Montenegro, Bosnia and Herzegovina }\end{array}$ & 34.790 \\
\hline \multicolumn{2}{|c|}{ CEFTA international trade balance } & +7.800 \\
\hline \multicolumn{3}{|c|}{ Eastern Europe Countries } \\
\hline Exporters & Belarus, Ukraine & 24.806 \\
\hline Importers & Russia & 550.540 \\
\hline \multicolumn{2}{|c|}{ Eastern Europe international trade balance } & -525.734 \\
\hline \multicolumn{3}{|c|}{ Developed European countries (EU15, Norway and Switzerland) } \\
\hline Exporters & Spain, Netherlands, Belgium, Portugal, Italy & 1.658 .251 \\
\hline Importers & $\begin{array}{l}\text { Germany, Great Britain, France, Sweden, } \\
\text { Austria, Denmark, Ireland, Finland, Greece }\end{array}$ & 1.644 .700 \\
\hline \multicolumn{2}{|c|}{$\begin{array}{l}\text { Developed European countries international trade } \\
\text { balance }\end{array}$} & +13.550 \\
\hline \multicolumn{3}{|c|}{ Other EU countries } \\
\hline Exporters & none & - \\
\hline Importers & $\begin{array}{l}\text { Czech Republic, Romania, Bulgaria, } \\
\text { Slovakia, Poland, Latvia, Estonia, Hungary, } \\
\text { Slovenia, Croatia }\end{array}$ & 258.098 \\
\hline \multicolumn{2}{|c|}{ Other EU countries international trade balance } & -258.098 \\
\hline \multicolumn{3}{|c|}{ Turkey } \\
\hline \multicolumn{2}{|c|}{ Turkey international trade balance } & +411.683 \\
\hline \multicolumn{2}{|c|}{$\begin{array}{l}\text { TOTAL fresh tomato international trade balance of } \\
\text { Europe }\end{array}$} & -350.799 \\
\hline
\end{tabular}

Source: Statistical office of Republic of Serbia

Four potential target markets were analyzed: Central European Free Trade region (CEFTA), eastern European countries (Russia, Belarus and Ukraine), developed European countries (EU15, Norway and Switzerland) and other EU countries.

Central European Free Trade market and the market of developed European countries have positive international trade balances indicating that these 
markets probably have higher barriers for entrance of fresh tomato from other regions established in competitive advantage. Thus for the country developing its export (and production) activities, in spite of the highest import prices (Table 3) the market of developed European countries is not likely to be accessible. The Central European Free Trade market is saturated with tomato from FYROM, followed with increasing exports from Albania that in comparison to Serbia have more convenient climatic conditions supporting production of cheap early season tomato sold at relatively low prices (Table 3) unlikely to contribute significantly to the generation of profits. However, the fact that the extremely hot climate during the summer period prevents tomato production in these countries during the summer might also represent one of the opportunities for Serbia.

Oppositely the markets of Eastern Europe and other EU countries (without EU15) are characterized with distinct negative international trade balance of fresh tomato with total deficit of fresh tomato ranging over $750.000 \mathrm{t}$ (Table 2) which is imported at relatively high prices of 0,77 and 1,08 USD/kg (Table 3) respectively.

The fact that the fresh tomato deficit at European markets is in large proportion satisfied with export of fresh tomato from Turkey of over $400.000 \mathrm{t}$ exported at average price of $0,66 \mathrm{USD} / \mathrm{kg}$ (Table 2) have to be emphasized and taken into account.

Table 3. Analysis of prices for potential target market for tomato

\begin{tabular}{|l|r|r|r|r|}
\hline & $\begin{array}{c}\text { Average } \\
(\text { USD/kg) }\end{array}$ & $\begin{array}{c}\text { Minimum } \\
(\text { USD/kg) }\end{array}$ & $\begin{array}{c}\text { Maximum } \\
(\text { USD/kg) }\end{array}$ & $\begin{array}{c}\text { Variation } \\
\text { coefficient (\%) }\end{array}$ \\
\hline Central European Free Trade - CEFTA 2006 \\
\hline Export & 0,49 & 0,20 & 1,39 & 39,87 \\
\hline Import & 0,58 & 0,29 & 1,13 & 35,82 \\
\hline European Countries of Former Soviet Union \\
\hline Export & 0,57 & 0,00 & 2,43 & 7,19 \\
\hline Import & 0,77 & 0,34 & 1,25 & 29,58 \\
\hline Developed European countries (EU15, Norway and Switzerland) \\
\hline Export \\
\hline Import & 1,77 & 0,19 & 4,36 & 39,97 \\
\hline Other EU countries & 1,61 & 0,25 & 3,31 & 31,94 \\
\hline Export & 1,20 & 0,41 & 2,82 & 16,04 \\
\hline Import & 1,08 & 0,15 & 1,63 \\
\hline Turkey
\end{tabular}

Source FAOSTAT 
Presented results clearly point out that there is a place for additional quantities of fresh tomato at proximate markets. At the other hand Serbia has agroclimatic and locational predispositions to fill this gap. However, the season in which tomato from Serbia might be available depends on the production practices to be adopted.

Figure 3. Structure of tomato supply chain in Serbia

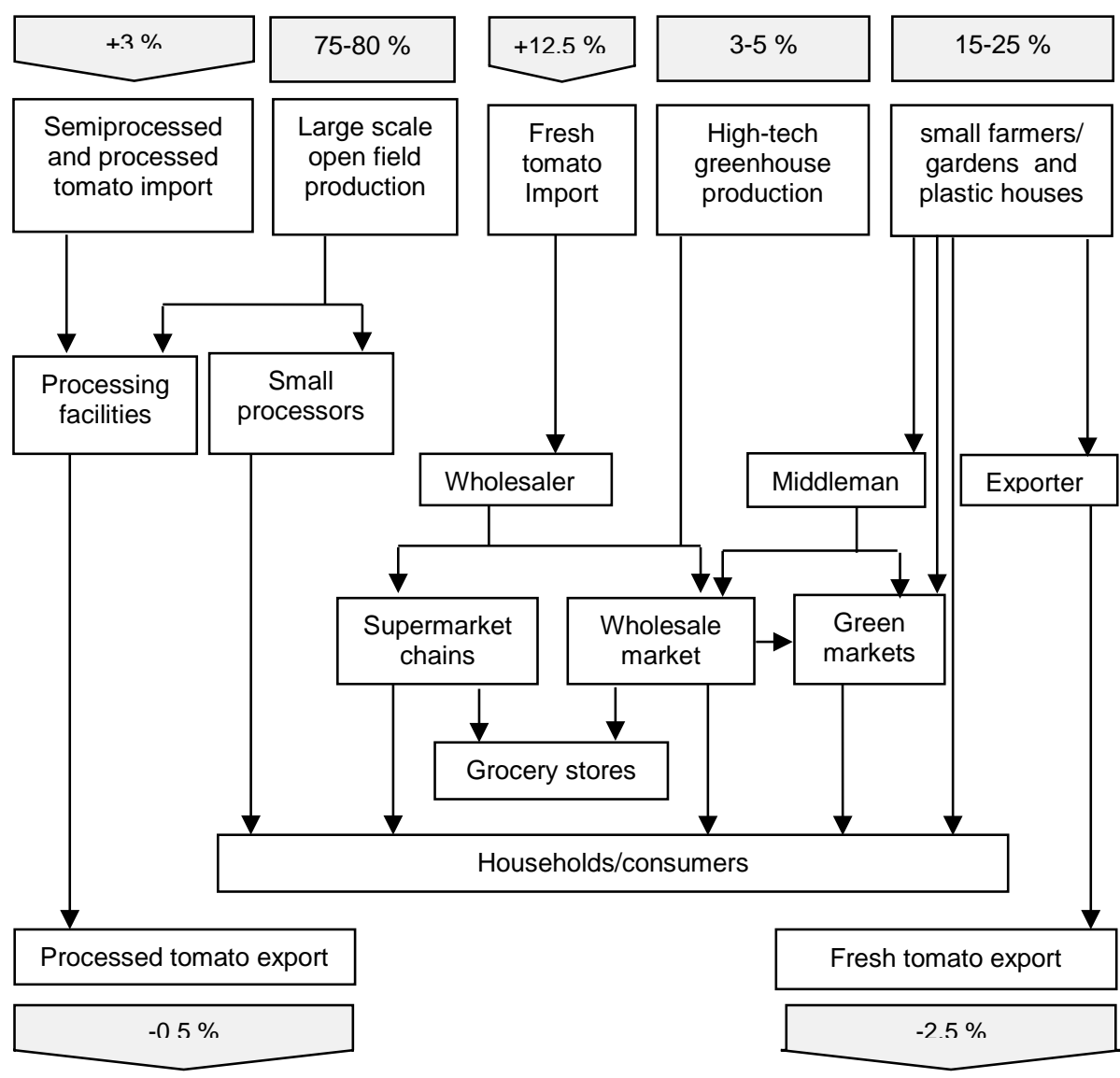

Legend Approximate shares of diverse production and distribution sectors in respect to total tomato production in Serbia $\left(,+{ }^{\prime \prime}-\right.$ importup up to the production; ,", - export from the production

In order to optimize the steps forward in utilization of existing potentials for tomato production for viable export the analysis of tomato supply chain was 
Vuković A. et al.: Fresh tomato: promising export product for Serbia?

conducted at the basis of interviews conducted with tomato supply chain stakeholders (Figure 3). Additionally, based on the data obtained from conducted interviews strengths, weaknesses, opportunities and threats of tomato production and supply chain in Serbia were systematized in SWOT analysis presented in Table 4.

Table 4. Overview of strengths, weaknesses, opportunities and threats (SWOT) of Serbian tomato sector

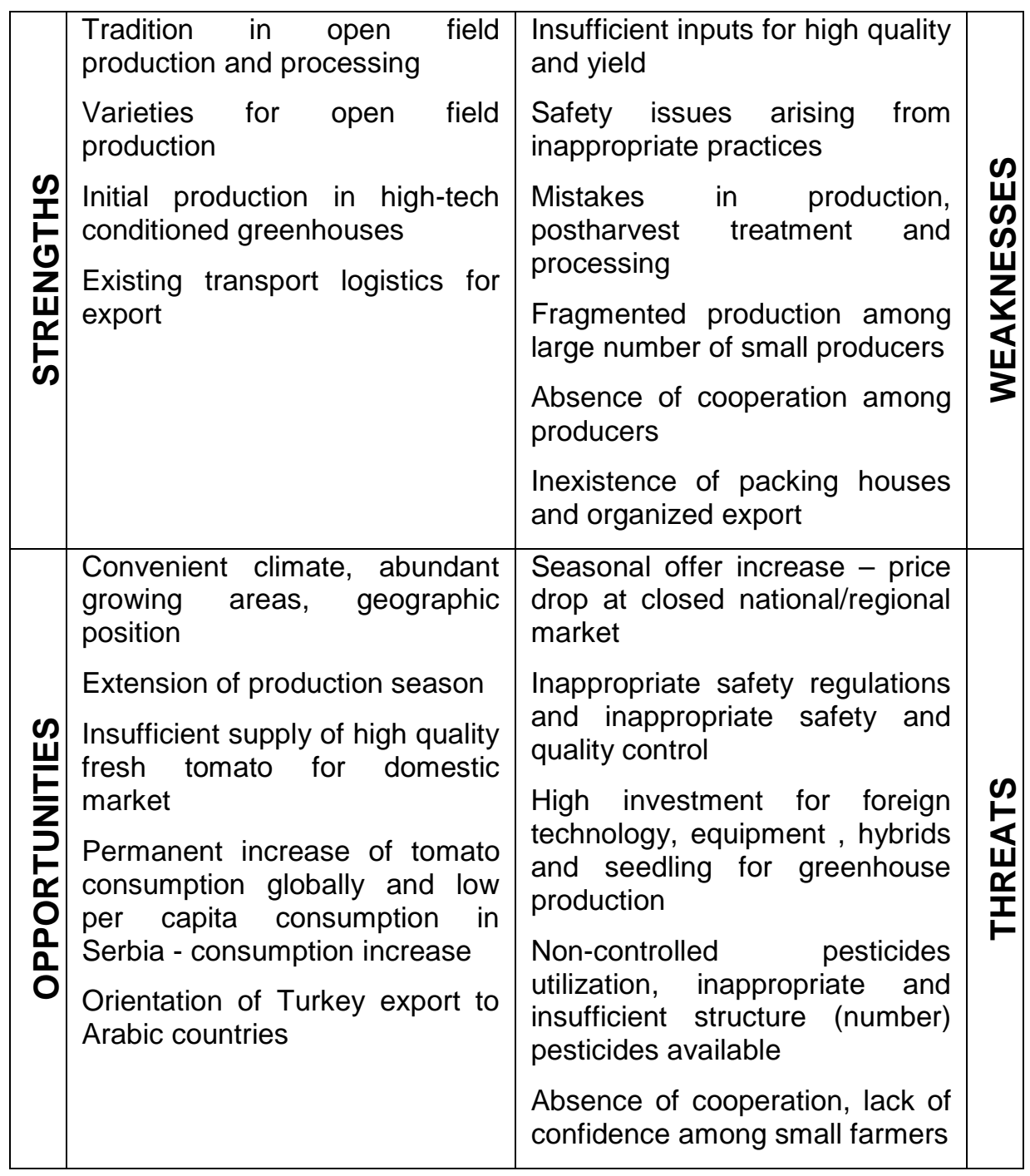


As derived from conducted interviews, tomato production in Serbia is divided into three sectors: open field production of tomato for industrial processing representing $75-80 \%$ of total tomato production, production of tomato for fresh consumption by small producers in open gardens or plastic houses/tunnels representing $15-25 \%$ of total tomato production, and production of tomato for fresh consumption in high tech conditioned greenhouses with application of the most recent technological solutions of integrated agricultural production, representing unfortunately only about 3-5 \% of total tomato production in Serbia.

The main quantities of tomato, produced in open field is available during very short season and delivered to tomato processors at prices multiply lower in respect to market price of tomato for fresh consumption. This sector, as well as the international trade balance of tomato products, as indicated by emphasized strengths and opportunities for this sector, obviously also deserve attention and analysis but this sector is not the focal issue of present research and thus will not be further discussed.

Production of tomato for fresh consumption in high-tech conditioned greenhouses is in its initial phase, represented, as outlined by the stakeholders in conducted interviews, at small areas of up to 15 ha. However, the fact that the first steps in this directions are already successfully taken and knowledge needed for this type of production obtained are the starting strengths in developing the opportunities for production of tomato for domestic market and export with application of advanced production technology. However in this sector numerous threats, including dependence on foreign technological solutions and supplies for integrated agricultural production (Živković and Popović, 2005), high investment needed (Asci et al., 2014) and high energy consumption (Đević and Dimitrijević, 2009, Dimitrijević et al., 2011) contribute to increased risks and more difficult making of decision to invest in this tomato production sector. At the other hand, production of tomato in greenhouses with application of advanced integrated production technology guaranties extremely high and stable yields.

Additionally, increasing demand of supermarket chains as the growing final sales point in the distribution channel for tomato produced in this sector is still import dependent in spite of the fact that total current production is distributed through this distribution channel. The prices obtained by producers of greenhouse tomato at domestic market are higher than the ones achieved at the current export markets of Serbia. Based on emphasized facts it is likely that the development of contemporary greenhouse production sector can be expected, but it will primarily be oriented to the satisfaction of domestic market demands with expected increase of demand in general and especially in the supermarkets as the final sales point of distribution channel used by this sector. At the point when supply of tomato produced in this sector satisfies 
demand of Serbian market, high quality and impeccable safety of produce obtained with application of the most contemporary technology will represent potential export product. As a resource that might contribute to development of this sector towards price based competitive advantages in international trade, the utilization of existing thermal underground waters as resource enabling production costs reduction for heating of greenhouses in the offseason period when tomato can be sold at the highest prices, should be considered.

Finally, majority of producers of tomato for fresh consumption in Serbia are small farmers producing tomato in small open field - gardens or in small plastic houses and tunnels without possibilities for heating, temperature and humidity control and utilization of biological pest control. In spite of the fact that the majority of tomato producers are positioned in this sector, due to fragmented, small production areas per producer this sector generates only $15-25 \%$ of total tomato production. Nevertheless, tomato production in this sector is labor intensive and contributes to decrease of unemployment in Serbia, while the low investments needed to initiate the production support the entrepreneurship in this sector. This sector satisfies large proportion of domestic market through direct marketing and green markets representing still important distribution channels for tomato in Serbia. Large number of unorganized producers generate during the top of production season significant surpluses of tomato making thus place for middleman organizing distribution to more distant wholesale and green markets and lowering the price of tomato, often under the break even level. Recently companies organizing export of fresh tomato started to operate and initiated the increase of exports of fresh tomato noted in Figure 2.

However, this tomato production sector is burdened with numerous weaknesses and threats that prevent faster export increase and better positioning of producers at domestic fresh tomato market. Among the most important weaknesses and threats the following can be listed:

- Insufficient inputs in production that will crop high quality tomato with high yields

- lack of knowledge among producers resulting in application of inappropriate production practices,

- non-controlled and non-monitored utilization of pesticides endangering product safety,

- unavailability of efficient pesticides and biological resources against pests at domestic market,

- inexistence of well-organized producers' associations and resistance and reluctance of producers to cooperate,

- inexistence of packing houses and inappropriate postharvest treatments. 
Vuković A. et al.: Fresh tomato: promising export product for Serbia?

Such situation results in inexistence of tomato lots of uniform, standardized quality and marketable quantity for export. The way forward in positioning fresh tomato as the export commodity in Serbia would be the development of strategic plan for overcoming of mentioned weaknesses and preventing listed threats of small-scale fresh tomato production sector, similarly to the practices of developed countries (Hambursch and Weber, 2014). Such approach might contribute to improvement of competitive position of small-scale tomato production sector and improve its ability to compensate the import of fresh tomato and generate quantities of fresh tomato for export to the less demanding markets of East and Central Europe.

\section{Conclusions}

Serbia is characterized with negative international trade balance in the sector of fresh tomato. Export of fresh tomato from Serbia is at low level with increasing trend, but the dominant stream in international trade is the two-way export-import with the countries of the region at low prices.

Convenient climate, soil and excellent geostrategic position point out that Serbia has potentials to overcome the import dependence and to produce export quantities of fresh tomato.

Remarkable deficit of fresh tomato imported at relatively high prices, emphasizes the market of Central and Eastern Europe as the most promising target market for tomato from Serbia, additionally supported with less demanding preferences of consumers at this market.

Tomato production in high-tech greenhouses with application of advanced technology of integrated production might represent export potential after it satisfies the demands for tomato produced in this sector at domestic market. However, high investment needed for initiation of tomato production in this sector make its development capital and investors dependent.

Production of fresh tomato by small producers represents opportunity of entrepreneurship development and for employment of qualified and nonqualified workforce, but it is burdened with numerous weaknesses. Development of strategic plan for overcoming of weaknesses and preventing of threats of small-scale fresh tomato production sector might be the way forward in positioning fresh tomato as the export commodity of Serbia.

Open field production for industrial purposes is the dominant tomato production sector in Serbia accompanied with low but increasing export of tomato products. Yet significant import of industrial tomato products was 
Vuković A. et al.: Fresh tomato: promising export product for Serbia?

noted. Deserved attention in future research should thus be devoted also to the analysis of open field tomato production and processing sector.

\section{References}

Anastasiadis, F., Van Dam, Y.K. (2014). Consumer driven supply chains: the case of Dutch organic tomato, Agricultural Engineering International: CIGR Journal, Special issue, 11-20.

Andrews, E., Lesage, P., Benoit, C., Parent, J., Norris, G., \& Reveret, J.-P. (2009). Life Cycle Attribute Assessment Case Study of Quebec Greenhouse Tomatoes, Journal of Industrial Ecology, Yale University, 13(4), 565- 578.

Aramyan, L.H., Meuwissen, M.P.M., Oude Lansink, A.G.J.M., Van der Vorst, J.G.A.J., Van Kooten, O., \& Van der Lans, I.A. (2009). The perceived impact of quality assurance systems on tomato supply chain performance, Total Quality Managemant, 20,(6), 633-653.

Asci, S., VanSickle, J.J., \& Cantliffe, D.J. (2014). Risk in Investment Decision Making and Greenhouse Tomato Production Expansion in Florida, International Food and Agribusiness Management Review, 17(4), 1-26.

Belović, M. M., Pestorić, M. V., Mastilović, J. S., \& Kevrešan, Ž. S. (2012). Identification and selection of the descriptors for establishing a sensory profile of tomato by a multidimensional approach. Food and Feed Research, 39(1), 33-39.

Clottey, VA., Karbo, N., \& Gyasi, KO. (2009), The tomato industry in northern Ghana: Production constraints and strategies to improve competitiveness, African Journal of Food, Agriculture, Nutrition and Development, 9(6), 1436-1451.

Codron, J.-M., Adanacioglu, H., Aubert, M., Boushina, Z., Ait El Mekki, A., Rousset, S., Tozanli, S., \& Yercan, M. (2014), The role of market forces and food safety institutions in the adoption of sustainable farming practices: The case of the fresh tomato export sector in Morocco and Turkey, Food Policy 49(1), 268-280.

Dimitrijević, A., Bajkin, A., Đević, M., \& Urošević, M. (2011). Energy productivity of the tomato greenhouse production. Journal on Processing and Energy in Agriculture, 15(3), 138-142.

Đević, M., \& Dimitrijević, A. (2009). Energy efficiency of the open filed and greenhouse tomato production. Poljoprivredna tehnika, 34(3), 39-45.

Đorović, M.,Stevanović, S., \& Lazić,V. (2008), Srbija na međunarodnom tržištu povrća, Industrija 36(3), 108-126.

Hambrusch, J., Weber, N. (2014). Lessons learned from the mid-term evaluation of the austrian national strategy for the fruit and vegetables sector, Economics of Agriculture, 61(1), 103-114.

http://webrzs.stat.gov.rs/WebSite/public/ReportView.aspx, accessed July 13, 2015

http://faostat3.fao.org/home/E , accessed July 13, 2015

Ignjatijević, S. Čavlin, M.,Đorđević, D. (2014). Measurement of comparative advantages of processed food sector of Serbia in the increasing the export, Economics of Agriculture, 61(3), 677-693. 
Vuković A. et al.: Fresh tomato: promising export product for Serbia?

Mojević, M. V., \& Tešanović, D. B. (2011). Influence of short anoxia treatment and maturity on quality and storage life of tomatoes. Journal of Agricultural Sciences, 56(2), 121-131.

Valenciano,P. J., Pérez Mesa, J.C., \& Mangin, J.P. (2008). The Spanish Tomato Export Sector of the Almeria Region: An Econometric Approach, International Atlantic Economic Society, 14(3), 316-328.

Peševski, M. (2006). The significance of the EU-countries for vegetable exports from the Republic of Macedonia. Ekonomika poljoprivrede, 53(1), 21-33.

Ponjičan, O., Babić, M., Bajkin, A., Radomirović, D., Findura, P., Radojčin, M., \& Pavkov, I. (2012). Determining physical and mechanical properties of fresh tomato fruit during handling. Journal on Processing and Energy in Agriculture, 16(3), 98-102.

Puškarić, A., Jeločnik, M., Ivanović, L.(2009). Analysis of Vegetable Production in the European Union with Retrospection on the Conditions in Republic of Serbia, Seria Ştiinţe Economice, BULETINUL Universităţii Petrol - Gaze din Ploieşti, 61(3), 36-43.

Radusin, T. I., Kevrešan, Ž. S., Mastilović, J. S., Novaković, A. R., \& Hajnal-Janić, E. P. (2013). Influence of different packaging solutions on qualitative and quantitative properties of fresh tomato variety Izmir during storage at market conditions. Food and Feed Research, 40(2), 85-92.

Rodriguez, G.M., Hernandez, J.J.C. (2005). Modeling weekly Canary tomato exports, Agricultural Economics, 33(3), 255-267.

Roggeveen, K. (2014). Tomato journeys from farm to fruit shop, Local Environment: The International Journal of Justice and Sustainability, 19(1), 77-102

Serin, V., Civan, A. (2008). Revealed Comparative Advantage and Competitiveness: A Case Study for Turkey towards the EU, Journal of Economic and Social Research 10(2), 25-41.

Sharma, G., Singh S.P. (2011). Economic Analysis of Post-harvest Losses in Marketing of Vegetables in Uttarakhand, Agricultural Economics Research Review, 24(2), 309-315.

Stratan, A. (2014). Moldovan agri-food sector dilemma: east or west?, Economics of Agriculture 61(3), 615-632.

Tahir, A., Shah, H., Sharif, M., Akhtar, W., \& Akmal N. (2012). An overview of tomato economy of Pakistan:comparative Analysis, Pakistan Journal Agricultural Research, 25(4), 288-294.

Takač, A., Gvozdenović, Đ., Bugarski, D., \& Červenski, J. (2007). Modern tomato production. Zbornik radova Instituta za ratarstvo i povrtarstvo, 43(1), 269-281.

Theurl, M.C., Haberl, H., Erb, K.-H., \& Lindenthal, T. (2014). Contrasted greenhouse gas emissions from local versus long-range tomato production, Agronomy for Sustainable Development, 34(3), 593-602.

Venus V., Kyei-Asare, D.K., Tijskens, L.M.M., Weir, M.J.C., De Bie, C.A.J.M., Ouedraogo, S., Nieuwenhuis, W., Wesselman, S.L.M., Cappelli, G.A., \& Smaling, E.M.A. (2013). Development and validation of a model to estimate postharvest losses during transport of tomatoes in West Africa, Computers and Electronics in Agriculture 92, 32-47.

Zdravković, J., Marković, Ž., Mijatović, M., \& Zdravković, M. (2009). The incorporation gene of tomato fruit firmness (Lycopersicon esculentum Mill.). Selekcija i semenarstvo, 15(2), 63-70. 
Vuković A. et al.: Fresh tomato: promising export product for Serbia?

Živković, D., \& Popović, N. (2005). Technological, organizational and economic properties of tomato production in greenhouse systems. Tehnika - Menadžment, 55(4), 5-10. 